ЕВОЛЮЦІЯ ТА ТРАНСФОРМАЦІЯ ТЕОРЕТИКО-ПРИКЛАДНИХ МЕХАНІЗМІВ ДЕРЖАВНОГО УПРАВЛІННЯ В УМОВАХ ДІДЖИТАЛІЗАЦІї (НА ПРИКЛАДІ СОЦІАЛЬНО-ЕКОНОМІЧНИХ ВІДНОСИН)

\title{
EVOLUTION AND TRANSFORMATION OF THEORETICAL-APPLIED MECHANISMS OF PUBLIC ADMINISTRATION IN THE CONDITIONS OF DIGITALIZATION (ON THE EXAMPLE OF SOCIO-ECONOMIC ASPECT)
}

у статті здійснено комплексне наукове обгрунтування та дослідження проблематики управління соціально-економічними відносинами в контексті простеження еволюції та трансорормації теоретико-прикладних механізмів державного управління в умовах діджиталізації крізь призму соціально-економічних відносин.

Акцентовано увагу на тому, що цисррова трансформація державного управління це автоматизація та оптимізація окремих процесів під час виконання державних функчій, в тому числі під час надання державних послуг, впровадження $і$ використання тих чи інших сучасних інноваційно-технологічних рішень та процесів в інтересах забезпечення діяльності державних органів, особливо в умовах діджиталізації, у соціально-економічних відносинах. Цифррова трансформація покликана якісно змінити зміст державного управління, в тому числі окремі його процедури, стадії управлінського циклу, державні функції, їх склад і типи, причому така зміна має приводити до підвищення якості державного управління: забезпечення більшої обгрунтованості державного втручання і зниження ролі держави загалом, підвищення результативності та ефективності діяльності органів державної влади. Підвищення рівня цифрровізації та діджиталізації державного управління тісно взаємопов'язано з підвищенням результативності державного управління, зниженням корупції, поліпшенням умов ведення бізнесу. Така якісна зміна, зви чайно, не означає, що державну політику буде здійснювати виключно штучний інтелект, однак цифрова трансорормація має на увазі, що деякі фрункції, виконувані сьогодні державними службовцями, будуть виконуватися в автоматичному режимі і не потребуватимуть втручання людини. Більшість державних послуг буде надаватися в електронному вигляді і не буде передбачати особистої взаємодії з органами влади на будьякому етапі. Всі стадії управлінського циклу будуть забезпечені актуальною і достовірною інфрормацією, необхідною для прийняття управлінських рішень, орієнтованих на кінцеві суспільно-значущі результати, а самі ці рішення будуть моделюватися і прийматися з використанням сучасних, в тому числі проривних, цифрових технологій. Зроблено висновок, про те, що і в Україні, $i$ в зарубіжних країнах вже традиційно цифрова трансформація розглядається перш за все як драйвер підвищення доступності та якості державних послуг. Але приклади застосування проривних цифррових технологій за кордоном показують, що їх потенціал не обмежується тільки цим типом державних фуункцій. Цифррові технології дозволяють трансорормувати здійснення всіх типів державних ффункцій і фуннцій по їх виконанню від нормотворчості до контрольно-наглядової діяльності та адміністрування доходів, що беззаперечно пов'язано із подальшими науково-теоретичними та нормативними дослідженнями.

Ключові слова: державне управління, соціально-економічні ризики, діджиталізація механізми державного управління, цифрова трансорормація.

The article provides a comprehensive scientific substantiation and study of the management of socio-economic relations in the context of tracing the evolution and transformation of theoretical and applied mechanisms of public administration in the context of digitalization through the prism of socio-economic relations.

Emphasis is placed on the fact that the digital transformation of public administration is not just the automation and optimization of certain processes in the provision of public functions, including the provision of public services, implementation and use of modern innovation and technological solutions and processes in the interests of public bodies, especially in the context of digitalization in socio-economic relations. The digital transformation is designed to qualitatively change the content of public administration, including its individual procedures, stages of the management cycle, public functions, their composition and types, and such a change should lead to improved quality of public administration: increasing the effectiveness and efficiency of public authorities. Increasing the level of digitalization and digitalization of public administration is closely interrelated with increasing the effectiveness of public administration, reducing corruption, improving the conditions for doing business. Such a qualitative change, of course, does not mean that public policy will be carried out exclusively by artificial intelligence, but the digital transformation implies that some functions performed today by civil servants will be performed automatically and will not require human intervention. Most public services will be provided electronically and will not involve personal interaction with the authorities at any stage. All stages of the management cycle will be provided with relevant and reliable information needed to make management decisions focused on the final socially significant results, and these decisions themselves will be modeled and made using modern, including breakthrough, digital technologies. It concluded that both in Ukraine and in foreign countries, digital transformation is traditionally seen primarily as a driver to improve the availability and quality of public services. But examples of the use of breakthrough digital technologies abroad show that their potential is not limited to this type of government function. Digital technologies allow to transform the implementation of all types of government functions and functions for their implementation from rule-making to control and supervision and revenue administration, which is undoubtedly associated with further scientific, theoretical and regulatory research. Key words: public administration, socio-economic risks, digitalization, mechanisms of public

administration, digital transformation.
Навчально-науково-виробничий центр Національного університету цивільного захисту України 
Постановка проблеми у загальному вигляді. Цифрова економіка $€$ складовою частиною економіки, де домінують знання суб'єктів і нематеріальне виробництво основний показник, що характеризує інформаційне суспільство. Основоположні поняття та категорії, такі як «цифрова економіка», «економіка знань», «інформаційне суспільство» і їх аналоги, представлені в сучасній науковій літературі, формують нову соціально-економічну систему, яка замінюе колишню індустріальну парадигму. У зв'язку з цим розвинені країни світу приділяють пильну увагу гармонійному розвитку системоутворюючих елементів цифрової економіки, інформаційного суспільства та економіки знань. Розуміння необхідності переходу до інформаційної економіки склалося і в Україні, що знайшло своє відображення в численних нормативних актах та програмах. Натомість у сучасних умовах розвитку та трансформації соціально-економічних відносин очевидною $€$ необхідність системних перетворень і дій, спрямованих на розвиток цифрової економіки у вітчизняних соціально-економічних системах всіх рівнів. Ідеєю цифрової трансформації охоплений весь світ, вона зараз є однією з найпопулярніших тем обговорень, але в дійсності це далеко не нове поняття, дискусія про яке йде вже кілька десятиліть. Беззаперечним постає той факт у науковому середовищі, що цифровізація та діджиталізація економіки представляють собою сучасну форму прояву більш фундаментальної закономірності її інформатизації, відтак пошук окремих теоретико-прикладних механізмів та їх науково-теоретичне обґрунтування виступають належними та ефективними засобами розвитку соціально-економічних відносин взагалі.

Аналіз останніх досліджень і публікацій. Теоретико-прикладні аспекти дослідження державного управління соціально-економічних відносин досить часто привертали увагу вітчизняних та закордонних вчених, зокрема таких, як А. Помаза-Пономаренко, О. Новікова, С. Робок, Ю. Саєнко, О. Сидорчук та інших. Водночас зазначені вчені зазвичай розглядали сферу державного управління загалом або намагалися виокремити лише окремі закономірності статусу тих чи інших органів державно-управлінської діяльності, функції яких спрямовані на соціально-економічний розвиток. Проблематика ж управління соціально-економічними відносинами, а особливо в контексті простеження еволюції та трансформації теоретико-прикладних механізмів державного управління в умовах діджиталізації, ще не отримала належного теоретико-прикладного обґрунтування та дослідження.
Внаслідок чого метою статті $€$ наукове обґрунтування та дослідження проблематики управління соціально-економічними відносинами, а особливо в контексті простеження еволюції та трансформації теоретико-прикладних механізмів державного управління в умовах діджиталізації крізь призму соціально-економічних відносин.

Виклад основного матеріалу. Цифрова трансформація в державному управлінні розглядається як одна з умов збереження конкурентоспроможності України в світовій економіці. Як наголошується на науковому рівні, лідерський потенціал нашої держави у цифровій трансформації, і не тільки в ній, навряд чи можна реалізувати, якщо не буде розвиватися цифровізація державного управління. Для оцінки потенціалу використання цифрових технологій у державному управлінні доцільно розглянути різні аспекти якості державного управління (обґрунтованість державного втручання, результативність і ефективність), а також проаналізувати потреби державного управління і виявити можливості і обмеження використання цифрових технологій для задоволення таких потреб [1, с. 120].

При цьому як критерії доцільності впровадження тих чи інших цифрових технологій у державному управлінні пропонується розглядати такі: результативність - впровадження тієї чи іншої цифрової технології, що повинно сприяти задоволенню потреб підвищення якості державного управління в цьому аспекті, а отже, забезпечувати підвищення результативності державного управління, відтак конкретні параметри, наприклад, впровадження технології, можуть привести до зниження термінів виконання тих чи інших державних функцій, появи нових суспільних благ, зниження частоти заподіяння шкоди тощо); економічна ефективність - впровадження тієї або іншої цифрової технології в державному управлінні, що має сприяти зниженню бюджетних витрат (як мінімум витрат на утримання апаратів, операційних витрат) та / або витрат громадян і організацій як мінімум в середньостроковій перспективі; зовнішня конкурентоспроможність - наявність заданих зовнішніми сторонами умов і параметрів, стандартів, очікувань (наприклад, рівень розвитку приватного сектора і очікування громадян щодо якісних характеристик надання державних послуг на основі досвіду їх взаємодії з приватними компаніями (отримання послуг, що надаються недержавними організаціями).

На глибоке переконання окремих науковців, та й згідно з результатами представлених державно-аналітичних досліджень, впрова- 
дженню принципів державного управління за результатами цифровізації та реалізації окремих аспектів діджиталізації перешкоджає відсутність оперативної і точної інформації про результати, що досягаються на всіх рівнях, а також значний часовий розрив між досягненням результатів і появою інформації про них [2, с. 205]. Переважання ручного введення даних про досягнуті результати в державні інформаційні системи підвищує ризики маніпулювання даними (їх навмисного спотворення). Можливості використання цифрових технологій для подальшого впровадження управління за результатами та підвищення результативності державного управління включають: використання великих даних і можливостей для формування статистики та використання в державному управлінні в режимі реального часу; отримання і обробку даних на основі міжмашинної взаємодії; використання технологій штучного інтелекту для аналізу даних і формування оптимальних рішень. За багатьма позначеними напрямами в зарубіжній практиці є приклади успішної реалізації. До них належать і проєкти з використання «великих даних» для цілей офіційного статистичного спостереження [3, с. 47]. Наприклад, для вивчення щоденної мобільності населення треба було співробітництво Інституту національної статистики Італії та оператора мобільного зв'язку. Для формування індексу споживчих цін на продовольчі товари Федеральний статистичний офіс Швейцарії використовував дані сканерів супермаркетів чотирьох основних роздрібних мереж, з якими він уклав партнерські угоди [4, с. 88].

За експертними оцінками, за умови уважного ставлення до стимулів та захисту персональних даних за допомогою спеціальних протоколів і угод, а також з урахуванням спільного використання статистичної та нестатистичної інформації, «великі дані» можуть грати важливу роль у підвищенні точності, своєчасності і якості економічної статистики за відносно низьких витрат порівняно з витратами на проведення додаткових обстежень традиційними методами. Іншими словами, використання «великих даних» для цілей формування статистики відповідає критеріям результативності та ефективності. Безумовно, $є$ і істотний потенціал підвищення результативності діяльності органів державної влади за рахунок цифрової трансформації як у сфері надання державних послуг, так і в сфері державного контролю (нагляду), адміністрування доходів, інших типів державних функцій [5, с. 61].

Водночас варто зауважити, що $є$ ряд правових, економічних, технологічних, організаційних та інфраструктурних обмежень циф- ровізації державного управління, без зняття (або істотного зниження) яких окремі напрями цифровізації можуть виявитися нерезультативними та/або неефективними. Ключовими ризиками впровадження цифрових технологій є: втрата керованості в критичних сферах державного управління; несанкціоноване використання персональних даних; можливість порушень прав людини під час автоматизованого прийняття управлінських рішень; організаційні ризики, в тому числі опір органів влади переходу від відомчої інформатизації до платформних рішень, тощо. Потенційне використання цифрових технологій здатне значно скоротити втручання держави в економічні та соціальні процеси, підвищити результативність та ефективність державного управління. Ефект, пов'язаний зі зниженням адміністративних витрат бізнесу, громадян і держави, підвищенням доступності державних (в широкому сенсі) послуг, рівня захищеності громадян і мінімізацією ризиків заподіяння шкоди в підконтрольних (піднаглядних) сферах, може бути істотним. До масового впровадження необхідне проведення окремих експериментів і пілотних проєктів (наприклад, з автоматичного збору статистичних даних), а також усунення інфраструктурних, правових і організаційних обмежень [6, с. 10-11].

Водночас у контексті еволюції та трансформації окремих механізмів державного управління в умовах діджиталізації стає очевидним, що виявлення та усунення правових обмежень для використання проривних інформаційних (цифрових) технологій у державному управлінні на рівні міжнародних організацій і в провідних зарубіжних країнах у цей час ведеться головним чином у двох напрямах. Перший напрям пов'язаний з традиційною для закордонного державного управління технологічною оцінкою (оцінкою впливу технологій), яка розвивається в тому числі в рамках Європейської мережі парламентської оцінки технологій. Впровадження технологічної оцінки в державне управління, в тому числі нормотворчого процесу, впливає на якість розвитку інформаційних технологій у державі, що відбивається у відповідних міжнародних рейтингах розвитку інформаційного суспільства, електронного уряду тощо. Другий напрям пов'язаний з проведенням експериментів щодо застосування цифрових технологій і виявлення кращих практик, відтак на основі аналізу кращих йде формування рекомендацій і нормативів у рамках міжнародних організацій [2, с. 90].

Ключове значення для використання цифрових технологій у державному управлінні та усунення правових обмежень мають три прин- 
ципи, відображені у стратегіях цифрового уряду та закріплені на міжнародному рівні, зокрема: забезпечення системного взаємозв'язку з прогнозуванням науково-технологічного розвитку; забезпечення комплексної оцінки впливу правового регулювання на розвиток цифрових технологій, включаючи участь у нормотворчому процесі всіх зацікавлених сторін; створення спеціальних правових режимів для проведення правових експериментів для застосування (використання) проривних цифрових технологій у державному управлінні соціально-економічних відносин [5, с. 63].

Наявні правові обмеження щодо впровадження і застосування (використання) цифрових технологій у державному управлінні можна поділити на загальні, характерні для їх правового регулювання, і спеціальні, пов'язані з окремими стадіями управлінського циклу державного управління або окремими типами державних функцій. До числа загальних правових обмежень на основі аналізу зарубіжного досвіду та вітчизняного правового регулювання належать: відсутність нормативного визначення базових понять самих цифрових технологій, загального правового режиму їх впровадження і використання та застосування. На цей час процес формування міжнародних і національних стандартів щодо цифрових технологій тільки відбувається.

Висновки. Таким чином, можна зробити висновок, що цифрова трансформація державного управління - це не просто автоматизація та оптимізація окремих процесів під час виконання державних функцій, в тому числі під час надання державних послуг, а й впровадження і використання тих чи інших сучасних інноваційно-технологічних рішень та процесів в інтересах забезпечення діяльності державних органів, особливо в умовах діджиталізації у соціально-економічних відносинах. Цифрова трансформація покликана якісно змінити зміст державного управління, в тому числі окремі його процедури, стадії управлінського циклу, державні функції, їх склад і типи. Причому така зміна має приводити до підвищення якості державного управління: забезпечення більшої обґрунтованості державного втручання і зниження ролі держави загалом, підвищення результативності та ефективності діяльності органів державної влади. Підвищення рівня цифровізації та діджиталізації державного управління тісно взаємопов'язано з підвищенням результативності державного управління, зниженням корупції, поліпшенням умов ведення бізнесу. Цифрові технології дозволяють трансформувати здійснення всіх типів державних функцій і функцій по їх виконанню від нормотворчості до контрольно-наглядової діяльності та адміністрування доходів, що беззаперечно пов'язано із подальшими науково-теоретичними та нормативними дослідженнями.

\section{ЛIТЕРАТУРА:}

1. Ковальчук К.Ф. Інноваційно-інвестиційна політика сталого розвитку регіонів України: від теорії до практики. Донецьк : ІМА-прес, 2012. 214 с.

2. Беликова Т.Ю., Мищенко С.Г. Управление стратегическим развитием жизнеспособных экономических систем: модели, механизмы и инструменты : монограсрия. Киев, 2012. 381 с.

3. Бандурка О.М. Державне регулювання економіки. Харків : Видавництво Університету внутр. справ, 2000. 160 с.

4. Бакуменко В.Д. Теоретичні та організаційні засади державного управління. Київ : Видавництво НАДУ, 2003. 210 с.

5. Грабар Н.С., Хмиров І.М. Становлення та трансорормація механізмів державного управління (на прикладі управління інтелектуально-інноваційними ресурсами економіки в Україні). Вісник НУЦЗУ. Серія «Державне управління». 2021. Вип. 1(14). с. 58-65.

6. Марчук $€$. Україна: нова парадигма поступу : аналітичне дослідження. Київ : Аваллон, 2001. 215 с. 